Int. J. Odontostomat.,

10(1):143-148, 2016.

\title{
Effectiveness of NaviTip FX on Intracanal Calcium Hydroxide Removal
}

\author{
Efectividad de NaviTip FX para la Remoción Intracanal de Hidróxido de Cálcio
}

\begin{abstract}
Fernando Bezerra Romualdo Silva*; Nathalia Carolina Fernandes Fagundes*; Bárbara Catarina Lima Nogueira*; Luciana Jorge Moraes Silva ${ }^{* * *}$ \& Rafael Rodrigues Lima*
\end{abstract}

SILVA, F. B. R.; FAGUNDES, N. C. F.; NOGUEIRA, B. C. L.; SILVA, L. J. M. \& LIMA, R. R. Effectiveness of NaviTip FX on intracanal calcium hydroxide removal. Int. J. Odontostomat., 10(1):143-148, 2016.

ABSTRACT: Remnants of calcium hydroxide $\left(\mathrm{Ca}(\mathrm{OH})_{2}\right)$ post-irrigation can compromise cleansing and permeability of dentinal walls in endodontic therapy. The aim of this study was to evaluate effectiveness of irrigation needle NaviTip FX on intracanal Calcium Hydroxide removal. Twenty-two single-rooted human teeth were randomly assigned according to irrigation needle used after calcium hydroxide removal: G1- NaviTip; G2- NaviTip FX, both with n= 9; as well as negative and positive control groups, with $n=2$. The samples were analyzed in scanning electron microscopy, with 500x magnification. The difference between groups were analysed by Student $t$ test, for $p \leq 0.01$. In apical third, G2 group presents better cleaning in comparison with $\mathrm{G} 1$ ( $p=0.0007)$. In middle third, no differences between groups were observed. NaviTip FX irrigation needle shows greater effectiveness in removing calcium hydroxide medication than NaviTip needle in the apical third of the canal.

KEY WORDS: calcium hydroxide, irrigant activation, root canal therapy.

\section{INTRODUCTION}

Disinfection of the root canal system is important to the success of endodontic therapy (Vilela et al., 2011). For this purpose, calcium hydroxide $\left(\mathrm{Ca}(\mathrm{OH})_{2}\right)$ is widely used as a root canal dressing between sessions (Lambrianidis et al., 2006; Kenne et al., 2006; Leonardo et al., 2006; Khedmat \& Shokouhinejad, 2008) due to the recognized antimicrobial, inhibiting osteoclast activity and promote tissue repair (Kuah et al., 2009). In contrast, the presence of post-Calcium Hydroxide instrumentation compromises the cleanliness and permeability of the dentin wall after the final watering (Goel et al., 2009). This framework difficult penetration of sealer in the dentinal tubules (Tasdemir et al., 2011), with potential to compromise a proper seal between the filling material and the walls of the conduit (Ahmetoglu et al., 2013; Shen et al., 2010).

Thus, the success of the therapy depends on the correct combination of steps instrumentation and irrigation (Al-Hadlaq et al., 2006). The complexity of the root canal irrigation becomes even more important since it allows cleaning beyond which can be achieved with mechanical instrumentation alone (Peters, 2004; Moradi et al., 2009), since the irrigant washing action, debris, microorganisms, tissues and medications are removed from the canal (Mancini et al., 2013; AbouRass \& Piccinino, 1982; Abi-Rached et al., 2014; Rödig et al., 2010). Therefore, many studies have been conducted to evaluate the effectiveness of techniques and chemicals used in irrigation stage (Gu et al., 2009; Foschi et al., 2004).

Removal of calcium hydroxide is usually carried out by final irrigation with Sodium Hypochlorite $(\mathrm{NaOCl})$ at different concentrations, agitation with thin gauge file and the associated $17 \%$ EDTA or ultrasonic agitation (Seraj et al., 2013; Sjogren et al., 1990). However, none of the above techniques are effective in removing all the material of canal walls, leaving up to $45 \%$ of the surface of the root canal covered with waste (Lambrianidis et al.).

\footnotetext{
* Structural Biology and Functional Laboratory, Biology Science Institute, Federal University of Pará, Pará, Brazil.

** Departament of Oral Pathology, School of Dentistry, Federal University of Pará, Pará, Brazil.

${ }^{* * *}$ School of Dentistry, Institute of Health Sciences, Federal University of Pará, Pará, Brazil.
} 
This research aimed to evaluate the effectiveness in removing $\mathrm{Ca}(\mathrm{OH})_{2}$ of the root canal of the middle and apical thirds, varying the type of irrigating cannula.

\section{MATERIAL AND METHOD}

Twenty-two single-rooted human teeth with fully formed apexes were used. The teeth were radiographed in the mesiodistal and buccal-palatal directions to confirm the criteria for inclusion in the study, such as absence of pulp calcifications, root cavities or canal atresia. Next, the teeth were placed in Timol $1 \%$ solution for two days, then rinsed in running water and stored in distilled water until the time of use. Occlusal surfaces were down using a single-faced steel disc to standardize tooth length at $21 \mathrm{~mm}$.

Surgical endodontic access was performed using the traditional technique with spherical 1013 diamond burs (KG Sorensen). Working length was established using a \#15 K-file (Dentsply/Maillefer, Petropolis, Brazil), introduced until it was visible in the apex. Next, the length was measured and the one millimeter was subtracted, obtaining the working length.

In order to create additional similarity to a clinical environment, screens were constructed using Speedex condensation silicone (Vigodent SA, Rio de Janeiro, Brazil) to simulate tooth sockets, to be used only during the instrumentation and irrigation stage. These "sockets" kept close contact with entire root, avoiding leakage of irrigating agents at apex. Thus, contributing to maintain the pressure of the intracanal irrigant.

The canals were prepared with ProTaper Universal (Denstply Malleifer, Petrópolis, Brazil), using a XSmart electric motor (Dentsply Malleifer, Petrópolis, Brazil), with torque control at $300 \mathrm{rpm}$ and $2 \mathrm{Ncm}$, by crown-down technique, according to manufacturer instructions up to to Finishing File 3 (F3) at work length, with irrigation of $5 \mathrm{~mL}$ Sodium hypochlorite at $1 \%$ after each instrument, and using the Endo-Eze irrigation needle (Ultradent Products Inc., South Jordan, United States).

After preparation, the teeth were subjected, in pairs, to ultrasonic bath (TD30 Plus; Bio-Art, São Carlos, Brazil) with distilled water for 2 min and dried using Protaper F3 (Denstply Malleifer, Petrópolis, Brazil). They were then filled in with a paste made with calcium hydroxide P. A. and distilled water $(3.4 \mathrm{~g} / 3 \mathrm{~mL})$, inserted with the aid of a Lentulo spiral \#35 from $3 \mathrm{~mm}$ to work length at low speed, until the excess paste could be observed in the apex. The access cavities were sealed with a cotton ball and temporary sealant (Coltosol; Vigodent SA, Rio de Janeiro, Brazil). The teeth were placed in an oven at average temperature of $37^{\circ} \mathrm{C}$ and $100 \%$ relative air humidity during $7 \mathrm{~d}$.

After that period, the teeth were randomly divided into two experimental groups: $\mathrm{G} 1$ and $\mathrm{G} 2$, according to the type of irrigation needle to be used to remove calcium hydroxide.

In $\mathrm{G} 1(\mathrm{n}=9)$, the medication was removed with the aid of a memory file used in the mechanical preparation (ProTaper F3) and NaviTip irrigation needle (no brush-covered), with \#30, using $5 \mathrm{~mL} \mathrm{NaOCl}$ at $1 \%$ and final irrigation with $1 \mathrm{ml}$ EDTA at $17 \%$ during $3 \mathrm{~min}$, followed by rinsing with $10 \mathrm{~mL}$ of $\mathrm{NaOCl}$ at $1 \%$. If any friction was detected, the needle was brought back 1 to $2 \mathrm{~mm}$ to facilitate reflux of the irrigation solution.

In $\mathrm{G} 2(\mathrm{n}=9)$, the medication was removed with the aid of a memory file used in the mechanical preparation (ProTaper F3) and NaviTip irrigation needle (brush-covered), with \#30, and the other stages were performed similarly to $\mathrm{G} 1$.

In positive control group (PCG), with $n=2$, the same entire sequence as the other groups were followed, except that their canals were not filled with calcium hydroxide paste, but had final irrigation with $1 \mathrm{~mL}$ of EDTA at $17 \%$ during $3 \mathrm{~min}$, followed by rinsing with $10 \mathrm{~mL}$ de $\mathrm{NaOCl}$ at $1 \%$.

In negative control group (NCG), with $n=2$, the same entire sequence as the other groups were followed, but the calcium hydroxide paste used to fill the canal was not removed.

After final irrigation, groups G1, G2 and PCG were dried using an aspiration needle and Protaper F3 (Denstply Malleifer, Petropolis, Brazil); the roots were cleaved longitudinally using a scalpel blade and a surgical hammer. Next, the samples were mounted on aluminum stubs, went trough additional oven drying, were metaled in platinum and examined under electronic scanning microscope - SEM (Carl Zeiss, Oberkochen, Germany), with program LEO-1430, 500x magnification.

To obtain the micrographs, the samples were placed so as the central SEM beam hit the center of 
apical and middle third of the root canal. Next, magnification was increased to $500 x$, and a grid was projected using LEO-1430, with sides approximately equal to $100 \mu \mathrm{m}$ by $100 \mu \mathrm{m}$, to capture the image (Fig. 1. A and B). The results were obtained by counting open dentinal tubules within the grid area. The data were

A

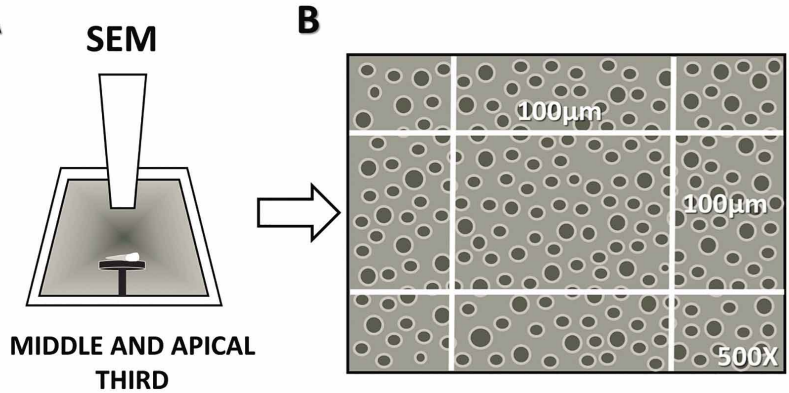

Fig. 1. A) Installation of teeth in stubs for analysis in scanning electron microscopy. B) Methodology of counting of dentinal tubules. compiled and evaluated statistically using Student's t test, with $p=0.01$ significance.

\section{RESULTS}

The dentinal tubule count analysis in the middle third (Fig. 2. A and B) showed no statistically significant difference $(p=0.2853)$ in the number of opened tubules, showing that the new method was no better cleaning tubules than the traditional method (Table I).

The dentinal tubule count analysis in apical third (Fig. 2.C and D) showed a statistically significant difference $(p=0.0007)$ in the number of opened tubules, showing that irrigation method using Navitip FX needle (G2) provided superior cleaning of dentinal tubules compared to NaviTip needle (G1) (Table I).

Table I. Mean and standard deviation (SD) of dentinal tubules, in $10 \mathrm{~mm}^{2}$, after irrigation in G1 (Navitip) and G2 (Navitip FX).

\begin{tabular}{llcc}
\hline & \multirow{2}{*}{ Third } & G1 group & G2 group \\
\cline { 3 - 4 } & & Mean (SD) & Mean (SD) \\
\hline Number of & Middle & $271.75( \pm 139.96)$ & $311( \pm 130.11)$ \\
tubules & Apical & $23.12( \pm 42.88)$ & $122.37( \pm 56.12)$ \\
\hline
\end{tabular}

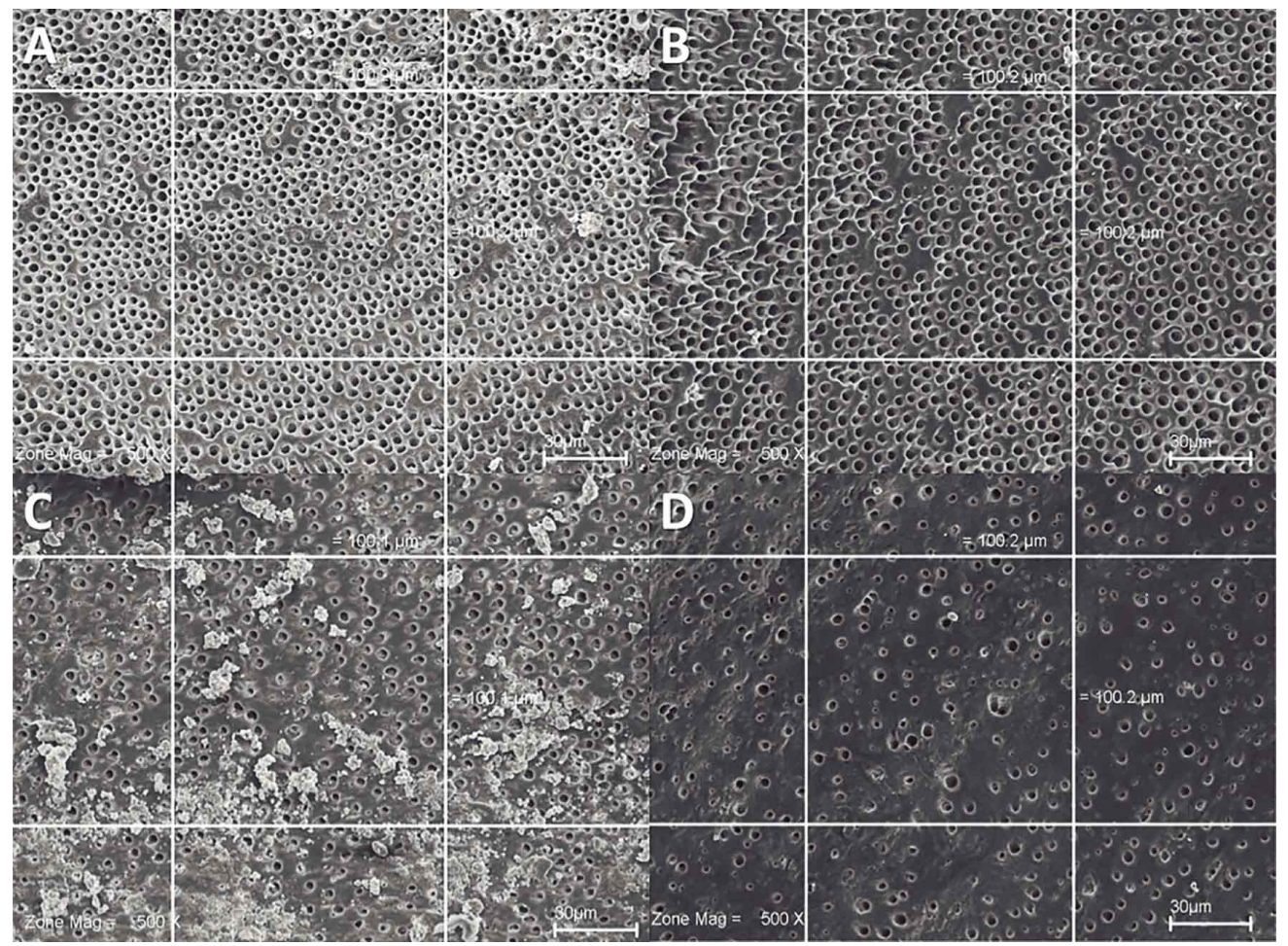

Fig. 2. SEM of the middle third of the dentin after using the NaviTip needle; A) and the NaviTip FX needle; B). SEM of the apical third of dentine after using the NaviTip, C). SEM of the apical third of the dentin after using the NaviTip FX needle (D). 


\section{DISCUSSION}

The use of NaviTip FX irrigation needle, with $1 \% \mathrm{NaOCl}$ and EDTA solution $17 \%$, was more efficient for Calcium Hydroxide removal in the apical third of the analyzed teeth. The middle third analysis showed no significant difference between the methods used.

The methodology used in this investigation, in which the dentinal tubules count clear the images obtained by scanning electron microscopy was performed, has in its practical implementation, great efficiency in achieving and analysis of results. This method allows a direct assessment of calcium hydroxide in the remaining dentin, and permits a quantitative analysis of the images. Furthermore, it has been the method of choice in similar studies in this, providing an effective comparison and discussion of results (Khedmat \& Shokouhinejad; Goel \& Tewari; Al-Hadlaq et al.).

The dental architecture, especially in dentin, is modified during endodontic treatment. Vigorous mechanical instrumentation on the dentinal walls exposed dentinal tubules of smaller diameter throughout the internal length of the root canal by changing the contact surface and the dentin surface tension of calcium hydroxide (Peters). This change in the relationship between the dentin and remnants of calcium hydroxide will reflect on microleakage and may lead to failure of endodontic therapy to not allow proper sealing capacity of the materials used during the filling stage (Moradi et al.).

The cleanliness of the middle and apical thirds has great significance in the elimination of pulp tissue remnants, microorganisms and their toxins from the root canal system (Peters; Mancini et al.; Abou-Rass et al.). Due to difficult access and insertion of filling material (Abi-Rached et al.; Rödig et al., 2010), the removal of calcium hydroxide paste of these regions shows crucial to the success of endodontic therapy.

The analysis of the calcium hydroxide in the removal of intracanal quality, associated with NaviTip FX needle with $\mathrm{NaClO}$ at $1 \%$ and EDTA $17 \%$ irrigation, is quite critical, since residues of $\mathrm{Ca}(\mathrm{OH})_{2}$ cannot be observed radiographically (Rödig et al., 2010) or clinically, and their permanence can directly affect the root filling (Gu et al.).
The effectiveness of NaviTip FX irrigation needle in removal of intracanal calcium hydroxide in the apical may be associated with the mechanical action of the bristles in the irrigation process, which increases the debridement of the root canal walls (Rödig et al., 2010; Foschi et al.), by close contact of the bristles in the apical portion of the canal and resulting mechanical friction.

In this sense, the mechanical preparation, either with rotary instruments or manual cleaning, ensures the cervical third, which was already highlighted the lack of debris, the presenceof dentinal tubules clear and significant removal of smear layer, featuring such region as an area not critical in the cleaning process and final irrigation (Seraj et al.; Sjogren et al.).

Due to the difficulty of access to the apical third, this region is presented with more complex for the removal of calcium hydroxide, which has been highlighted by using an irrigating agent. Most aggregation of calcium hydroxide residues may also be associated with the curvature of the canal type used irrigant and its depth of penetration (Vera et al., 2012; Rödig et al., 2011).

Furthermore, histological characteristics of the apical third (smaller diameter of dentinal tubules) may be configured as an adverse factor for the removal of calcium hydroxide, since the moment in which remnants of intracanal medicaments are housed in small lumen such tubules, drainage becomes less effective (Faria et al., 2013).

However, the largest diameter of this canal in the middle third, and consequently, the absence of contact of the bristle walls, can be a factor resulting in no significant difference in the middle third of the evaluation.

The results should be carefully assessed against the caliber of both irrigation needles, equal to the instrument memory. Although the cannulas have a standard "ideal", as flexibility, thin diameter and irrigant delivery capacity near the working length, the presence of a memory file equal to the instrument meets the proposal that the caliber of the needle smaller than the size of the canal after instrumentation (Sjogren et al.). The use of the same caliber needle to a solution would reduce the reflux in the most apical region, and hence the cleanliness. 
Also, it is recommended that the needle be placed as close as possible to working length, in order to increase irrigation efficacy (Shen et al.), but with equal caliber of the needle in root preparation, hinders the needle irrigation access to the working length. Another factor to be assessed is that, although it has been found in this investigation cleaning difference in the apical third, the NaviTip FX needle does not present micro-brush in $2 \mathrm{~mm}$ from the tip, so that area resembles to NaviTip needle.

The presence of different results may be explained by two factors: the incoming and outgoing movement of the needle in the irrigation process, and the approximate diameter of the light postinstrumentation canal and caliber of NaviTip FX. During the rollback of NaviTip FX, bristles keep contact with the dentin walls, hindering the return of the solution and promoting, in the area between the tip of the needle and the working limit a pressure greater irrigating fluid and turbulent flow to the vicinity of bristles or between them. Thus, the washing action with the use of NaviTip FX may have been facilitated by the change in flow dynamics.

The results of this study shows that, regardless of the type of needle, remainings of $\mathrm{Ca}(\mathrm{OH})_{2}$ were found in the apical third of both groups, so it is necessary to improve the irrigation technique associated with NaviTip FX to increase the success in removing of calcium hydroxide intracanal medication, since the permanence of these residues may cause the apical microleakage by dissolving in contact with tissue fluids (Leonardo et al.; Tasdemir et al.; Al-Hadlaq et al.).

The results of the methodology applied in this investigation indicated that the NaviTip FX irrigation needle used during the calcium hydroxide removal process, combined with $\mathrm{NaOCl}$ at $1 \%$ and EDTA $17 \%$ solution, was the most efficient in cleaning the apical third of straight-rooted teeth, with no significant difference in the middle third.

SILVA, F. B. R.; FAGUNDES, N. C. F.; NOGUEIRA, B. C. L.; SILVA, L. J. M. \& LIMA, R. R. Efectividad de NaviTip FX para la remoción intracanal de hidróxido de cálcio. Int. J. Odontostomat., 10(1):143-148, 2016.

RESUMEN: La presencia de hidróxido de calcio post-irrigación compromete la limpieza y la permeabilidad de la pared de la dentina durante el tratamiento endodóntico. El objetivo deste estudio fue evaluar la eficacia de la cánula de irrigación Navitip Fx en la eliminación de hidróxido de cálcio intracanalicular. Veintidós dientes unirradiculares humanos fueron divididos aleatoriamente de acuerdo con la cánula de irrigación, después de la eliminación del hidróxido de calcio, en grupos: G1- Navitip; G2- Navitip FX, ambos con n= 9; así como los grupos de control positivos y negativos, con n= 2. Las muestras fueron analizadas bajo microscopía electrónica de barrido, con magnificación de 500x. La diferencia entre los grupos fue analizada con la prueba t de Student $(p \leq 0,01)$. En el tercio apical, el grupo $\mathrm{G} 2$ presentó mejor limpieza en comparación con el grupo G1 ( $p=0,0007$ ). En el tercio medio, no se observaron diferencias entre los grupos. La cánula de irrigación Navitip FX muestra una mayor eficiencia en la eliminación de la medicación hidróxido de calcio en comparación con Navitip cánula en el tercio apical del canal.

PALABRAS CLAVE: hidróxido de cálcio, irrigantes del canal radicular, tratamiento del canal radicular.

\section{REFERENCES}

Abi-Rached, G. P.; Herrera, D. R.; Zaia, A. A.; Ferraz, C. C.; Almeida, J. F. \& Gomes, B. P. Efficacy of ethylene-diaminetetra-acetic acid associated with chlorhexidine on intracanal medication removal: a scanning electron microscopy study. Microsc. Res. Tech., 77(9):735-9, 2014.

Abou-Rass, M. \& Piccinino, M. V. The effectiveness of four clinical irrigation methods on the removal of root canal debris. Oral Surg. Oral Med. Oral Pathol., 54(3):323-8, 1982.

Ahmetoglu, F.; Simsek, N.; Keles, A.; Ocak, M. S. \& Er, K. Efficacy of self-adjusting file and passive ultrasonic irrigation on removing calcium hydroxide from root canals. Dent. Mater. J., 32(6):1005-10, 2013.
Al-Hadlaq, S. M.; Al-Turaiki, S. A.; Al-Sulami, U. \& Saad, A. $Y$. Efficacy of a new brush-covered irrigation needle in removing root canal debris: a scanning electron microscopic study. J. Endod., 32(12):1181-4, 2006.

Faria, G.; Kuga, M. C.; Ruy, A. C.; Aranda-Garcia, A. J.; Bonetti-Filho, I.; Guerreiro-Tanomaru, J. M. \& Leonardo, R. T. The efficacy of the self-adjusting file and ProTaper for removal of calciumhydroxide from root canals. J. Appl. Oral Sci., 21(4):346-50, 2013.

Foschi, F.; Nucci, C.; Montebugnoli, L.; Marchionni, S.; Breschi, L.; Malagnino, V. A. \& Prati, C. SEM evaluation of canal wall dentine following use of Mtwo and ProTaper NiTi rotary instruments. Int. Endod. J., 37(12):832-9, 2004. 
Goel, S. \& Tewari, S. Smear layer removal with passive ultrasonic irrigation and the NaviTip FX: a scanning electron microscopic study. Oral Surg. Oral Med. Oral Pathol. Oral Radiol. Endod., 108(3):465-70, 2009.

Gu, L. S.; Kim, J. R.; Ling, J.; Choi, K. K.; Pashley, D. H. \& Tay, F. R. Review of contemporary irrigant agitation techniques and devices. J. Endod., 35(6):791-804, 2009.

Kenee, D. M.; Allemang, J. D.; Johnson, J. D.; Hellstein, J. \& Nichol, B. K. A quantitative assessment of efficacy of various calcium hydroxide removal techniques. J. Endod., 32(6):563-5, 2006

Khedmat, S. \& Shokouhinejad, N. Comparison of the efficacy of three chelating agents in smear layer removal. $J$. Endod., 34(5):599-602, 2008.

Kuah, H. G.; Lui, J. N.; Tseng, P. S. \& Chen, N. N. The effect of EDTA with and without ultrasonics on removal of the smear layer. J. Endod., 35(3):393-6, 2009.

Lambrianidis T.; Kosti, E.; Boutsioukis, C. \& Mazinis, M. Removal efficacy of various calcium hydroxide/ chlorhexidine medicaments from the root canal. Int. Endod. J., 39(1):55-61, 2006.

Leonardo, M. R.; Hernandez, M. E.; Silva, L. A. \& TanomaruFilho, M. Effect of a calcium hydroxide-based root canal dressing on periapical repair in dogs: a histological study. Oral Surg. Oral Med. Oral Pathol. Oral Radiol. Endod., 102(5):680-5, 2006.

Mancini, M.; Cerroni, L.; Iorio, L.; Armellin, E.; Conte, G. \& Cianconi, L. Smear layer removal and canal cleanliness using different irrigation systems (EndoActivator, EndoVac, and passive ultrasonic irrigation): field emission scanning electron microscopic evaluation in an in vitro study. J. Endod., 39(11):1456-60, 2013.

Moradi, S.; Naghavi, N.; Rohani, E. \& Javidi, M. Evaluation of microleakage following application of a dentin bonding agent as root canal sealer in the presence or absence of smear layer. J. Oral Sci., 51(2):207-13, 2009.

Peters, O. A. Current challenges and concepts in the preparation of root canal systems: a review. J. Endod., 30(8):559-67, 2004.

Rödig, T.; Döllmann. S.; Konietschke, F.; Drebenstedt, S. \& Hülsmann, M. Effectiveness of different irrigant agitation techniques on debris and smear layer removal in curved root canals: a scanning electron microscopy study. J. Endod., 36(12):1983-7, 2010.

Rödig, T.; Hirschleb, M.; Zapf, A. \& Hülsmann, M. Comparison of ultrasonic irrigation and RinsEndo for the removal of calcium hydroxide and Ledermix paste from root canals. Int. Endod. J., 44(12):1155-61, 2011.
Seraj, B.; Ramezani, G.; Ghadimi, S.; Mosharrafian, S. H.; Motahhary, P. \& Safari, M. In-vitro comparison of instrumentation time and cleaning capacity between endodontic handpiece and manual preparation techniques in primary molar teeth. Minerva Stomatol., 62(1-2):17-22, 2013.

Shen, Y.; Gao, Y.; Qian, W.; Ruse, N. D.; Zhou, X.; Wu, H. \& Haapasalo, M. Three-dimensional numeric simulation of root canal irrigant flow with different irrigation needles. J. Endod., 36(5):884-9, 2010.

Sjogren, U.; Hagglund, B.; Sundqvist, G. \& Wing, K. Factors affecting the long-term results of endodontic treatment. J. Endod., 16(10):498-504, 1990.

Tasdemir, T.; Celik, D.; Er, K.; Yildirim, T.; Ceyhanli, K. T. \& Yesilyurt, C. Efficacy of several techniques for the removal of calcium hydroxide medicament from root canals. Int. Endod. J., 44(6):505-9, 2011.

Vera, J.; Hernández, E. M.; Romero, M.; Arias, A. \& van der Sluis, L. W. Effect of maintaining apical patency on irrigant penetration into the apical two millimeters of large root canals: an in vivo study. J. Endod., 38(10):1340-3, 2012.

Vilela, D. D.; Neto, M. M.; Villela, A. M. \& Pithon, M. M. Evaluation of interference of calcium hydroxide-based intracanal medication in filling root canal systems. J. Contemp. Dent. Pract., 12(5):368-71, 2011.

Correspondence to:

Bárbara Catarina Lima Nogueira

Departament of Oral Pathology

School of Dentistry

Federal University of Pará

Pará

BRAZIL

Email: barbara.nogueira@outlook.com.br

Received: 07-06-2015

Accepted: 03-02-2016 